\title{
SKIN BLEACHING AND WOMEN SEXUALISATION: A DISCOURSE ANALYSIS OF FELA KUTI'S YELLOW FEVER AND AYINLA OMOWURA'S ORO KAN JE MI LOGUN
}

*Israel A. FADIPE, Ph.D.

\begin{abstract}
Male music artistes have been observed to sexualise women in their songs, especially when commenting on societal problems. Employing van Dijk's Socio-Cognitive Approach of Critical Discourse Analysis (CDA), this paper examined skin bleaching and women sexualisation in the lyrics of Fela Anikulapo-Kuti (Fela Kuti) and Ayinla Omowura. Both songs: Yellow Fever by the latter and Oro kan je mi logun (a matter concerns me) by the former were purposively selected based on popularity and thematic preoccupation, and analysed using linguistic and argumentative strategies. Findings showed persistent sexualisation of women in the songs that were meant to teach morals in the society. Therefore, this exposes the artistes as incurably prejudiced in spite of their best intention.
\end{abstract}

Keywords: Skin bleaching, Women sexualisation, Popular music, Fela Kuti, Ayinla Omowura

\section{Introduction}

Fela Anikulapo-Kuti (Fela Kuti) and Ayinla Omowura in the seventies and eighties devoted attention in their songs to the critique of skin bleaching practice among young women in Nigeria. As a result, the devotion has beamed searchlight on how these artistes have sexualised women in their songs. More so, skin bleaching practice is one postindependence phenomenon in Africa that is located in gender and sexuality discourses. This view is further reinforced by OloruntobaOju $(2011$, p. 3) when he posits that "sexual experience and sexual expression are modified by factors of history, society and culture." Despite these factors, it is pertinent to examine some of the issues these male artistes engaged in their songs. For instance, Balder (2005) discloses heteronormative beliefs in Chilean society which are reproduced by heterosexists' commentaries on sexualities of gendered

*Israel A. FADIPE, Ph.D. is of the Department of Mass Communication, Chrisland University, Abeokuta, Nigeria

Email: ia.fadipe@chrislanduniversity.edu.ng 
minorities through various discursive forms such as songs. Although her study focuses only on the critique of homosexual minorities by male heterosexuals, it was able to establish the effects of the censoring commentaries on minorities' sexuality, which is one of the concepts in this article as it relates to women. Her focus is, however, different from Makura's (2016) observation of Paul Matavire, the late blind Zimbabwean musician, who glorified patriarchy by portraying women as subservient to the masculine gender in some of his songs.

The discourse on skin bleaching practice may explicate the quest for identity formation among Africans generally whose cultures have been disparaged by the colonial forces of media imperialism as inferior (Igboin, 2011). Incidentally, discourses on these concepts have been documented in different media of communication such as radio, television, newspapers and books by media and culture researchers. As a matter of fact, popular music artistes have been noted to play different prominent roles in African societies, which range from protesting societal ills, commenting on government affairs to sensitising people about their fundamental rights (Olorunyomi, 2005; Olukotun, 2005). Beyond this, Iwilade (2010) decried the discriminatory disposition of popular music towards portrayal of women. Equally, Robinson (2011, p. 217) confirms that "the media serves as an effective means of socialization and transmission of popular culture. Mass media and popular culture have an interdependent relationship". Notwithstanding the relationship, both Iwilade and Robinson's submissions actually show mass media as agents of popular culture. This may mean that popular music artistes as agents of socialisation and cultural transmission may have been conditioned to negatively portray women sexuality because mass media inevitably are disposed to giving bias coverage to female gender.

Dahl, Sengupta and Vohs (2009) claim that the male understanding and fixation on sex is based on physical gratification and recreational activity, which may further explain why male music artistes under discussion appear to sexualise women while disparaging skin bleaching practice. Furthermore, Oloruntoba-Oju (2011) observes that impressions of sexuality are formed very early in life with the appreciation of biological differences and linguistic identification of sexual differences. This may underlie the reason male popular music artistes sexualise women in their music. In the same vein, Fei (2014) asserts that male popular music artistes have assigned different attributes to women: provider, forgiver and the healer, besides being tagged as objects of men's pleasure. Based on the foregoing, it is worthy to explore and compare how Fela Kuti and Ayinla Omowura apportion attributes in their songs to women in their quest to criticise skin bleaching practice among women in their society considering the 
above assumptions about male inclination to sexualise women. Olufela Olusegun Anikulapo-Kuti and Abdul Waheed Ayinla Yusuf Omowura were born in Abeokuta, their native birthplace in the 1930s and died in 1997 and 1980 respectively. While Fela acquired formal education by training as a musician and being social crusader by vocation singing in Yoruba, English and Pidgin English, Ayinla received informal education by being an apprentice in his father's blacksmith business, a music apprentice with his grandfather's band and a cab driver. Though Fela's music has more coverage because of language employed than Ayinla's music, both devoted ample time to pass commentaries on events and societal ills in their times.

\section{Patriarchy Influence, Women Sexualisation and Skin Bleaching Practice in Nigeria}

Beside popular music aiding sexualisation discourse in skin bleaching practice of women, the concept of patriarchy also has a great influence on mass media production of popular culture. As a matter of fact, not much understanding of societal obsession of female anatomy can be achieved without having a keen understanding of masculinity nature which engendered the concept of patriarchy and readily found in sundry cultural practices in existence. Patriarchy is a system of male authority which oppresses women through its social, political and economic institutions. Makama (2013) explains that:

The patriarchal society sets the parameters for women's structurally unequal position in families and markets by condoning genderdifferential terms in inheritance rights and legal adulthood, by tacitly condoning domestic and sexual violence and sanctioning differential wages for equal or comparable work. (p.116)

Patriarchal society only reproduces itself in any form or medium of communication that people utilise, such as the one music artistes employ in the discourse of skin bleaching and women sexuality. Thus, mass media and media practitioners can constitute a form of consent or stamp that continues to strengthen patriarchy. On the other hand, the concept of women sexualisation in the context of this study will not be complete without foregrounding it in understanding women from the angle of Yoruba culture and society, as the dialectics of skin bleaching practice concerns the examination of lyrical contents of two prominent Egba Yoruba music artistes:FelaKuti and AyinlaOmowura. Therefore, this explanation helps give more clarity to these artistes' lyrics as they talk about skin bleaching practice among women.As a 
matter of fact, sexuality ordinarily should not be repressed because it is part of human nature. However, Foucault (1978) admits that:

\begin{abstract}
It appears rather as an especially dense transfer point for relations of power: between men and women, young people and old people, parents and offspring, teachers and students, priests and laity, an administration and a population. Sexuality is not the most intractable element in power relations, but rather one of those endowed with the greatest instrumentality: useful for the greatest number of manoeuvres and capable of serving as a point of support, as a linchpin, for the most varied strategies. (p. 103)
\end{abstract}

It is evident that women sexualistion is synonymous to power and control being exerted on the others in any society. This means that it can be an instrument used in gendered situations. Foucault's examples encapsulate sex, age and religion, which describe how discrimination is exercised through these differences. Moreover, he outlined four major preoccupations with sex, one of whichthat is critical to the study, is the hysterisation of women's bodies. This is a situation when "the feminine body was analysed-qualified and disqualified-as being thoroughly saturated with sexuality"Foucault (1978:105). This is how different agents of socialisation have come to perceive women sexuality over time. This reflects in people's knowledge and language when relating any issue with women in every society. Olajubu (2003) says, I will argue that principles of gender relations and construction differ from one society to another. Further, the presence of hierarchical struc- tures among the Yoruba conûrms to a certain extent the existence of an ideology of difference and as a consequence, gender constructs (p. 21).

These gender constructs are what agents such as popular music artistes improvise in their various lyrics to portray people, especially women. Still, she believes these are not new in Yoruba culture as they were already there as roles assigned to being male and female in the society. They are not different fromFei's attributes of women which have been highlighted above. Like discourse on women sexualisation which has been engaged by popular artistes at different times in the twentieth century, skin bleaching practice also has history, especially among the black people wherever they have been found in the world. Ajose (2005), Charles (2010), Hunter (2011), and Durosaro, Ajiboye and Oniye (2012) have all examined the historical significance of skin bleaching practice in terms of colonialism, globalisation, health 
implications and self or community-pride. According to Charles (2010), people of colour in North America, Africa, the Caribbean, Europe, and Asia all practise skin bleaching. He adduced the practice in Jamaica to cultural domination of blacks by whites, social benefits ascribed to colourism, quest to improve physical appearance, and need for social acceptance. Hunter (2011), on the other hand, posits that the discourse of beauty, public health, and new cosmetic surgery discovery frames skin-lightening, body manipulation, and social actors in different and important ways, revealing much about the global beauty industry, neocolonial and post-colonial racial ideologies, and the ongoing role of women of color's bodies as the battleground for these conflicts ( $p$. 143).

The emphasis on the collusion of old and new technologies and ideologies of colonialism and race as they relate to the practice of skin bleaching is also mentioned by the author. Consequently, the overall idea and ideal of whitening is equal to beauty, appears to have gained much popularity more than before. Durosaye et al. (2012) in consonance observe that skin bleaching has become a popular practice among individuals of different age groups, gender and religious affiliations in Nigeria in spite of its social, pathological, physiological and psychological effects. Perry (2006) in her article, Buying White Beauty, examines the phenomenon of skin-bleaching as an issue which provides a provocative view of the intersection of race, poverty, and globalization in the contemporary world. She believes that this phenomenon is significantly driven by those who encourage perpetual social stratifications and subjugation in poor African countries.Thus, skin bleaching practice is an intractable attitude that has defied many odds to still be an issue till this day. At this point, it is expedient to know how the discourse of skin bleaching practice has been engaged by social agents as musicians in the Nigerian society.

\section{Critical Discourse Analysis (CDA): Socio-Cognitive Approach}

This study adopts qualitative method of data gathering and analysis using Critical Discourse Analysis (CDA). Aboh and Uduk (2017) identified three approaches in Critical Discourse Analysis; van Dijk's Socio-Cognitive Approach, which affords the opportunity of interaction between texts and inter-texualities, and of exploring the connection between discourse and social inequality is further adopted. All the released albums of the artistes constituted the population of the study, but two songs (Yellow Fever and Oro kan je mi logun -A matter concerns me), one from each artiste were purposively sampled due to their thematic preoccupation and popularity among the artistes' fans. These songs were downloaded from Youtube, listened to, transcribed and 
translated into English for critical analysis, employing linguistic (agency or nominalisation and lexical choice) and argumentative strategies (process of production and reception, creator of text, contexts, reasons, audience, potential meanings and intertexuality).

\section{The Discourse of Skin Bleaching in Fela Kuti and Ayinla Omowura's Songs}

The language of both Fela-Kuti's song, Yellow Fever and Ayinla Omowura's own, Ọọ kan jẹmí ló gún (l'm concerned about an issue) are Pidgin English and Yoruba respectively. The select song-texts are taken from their albums: Yellow Fever/Na Poi,(1976) and Vol. 15-Ati D'àríyq, (1979) (We've become accepted). Fela's song-text contains 8 stanzas with 3 different choruses intermingling them which he employed to reinforce the subject matter of skin bleaching practice. Similarly, after transcription and translation, Ayinla's own has 8 stanzas imbued with a sole, melodious chorus which he used to emphasise his messages on skin bleaching. Theseselectsong-texts reflect van Leeuwen's (2012) depiction of Lomas' (1968) understanding of African style of music, which involves discursive rendition between leader and chorus or call-response patterns, which is homophonic naturally. As a matter of fact, the artistes' choruses which are often repeatedduring rendition are insightful for they are embedded with censoring messages by the musicians reinforcing the crux of the discourses, as well as impactful because they are directed against women in their society.

\section{[Excerpt 1]}

Nigerian Pidgin English

Na him dey bring the matter now

he dey! (Fela)

\section{English Translation}

It is what brought up the matter

It's real

The social agents described by Fela in Excerpt 1 are skin bleachingpractice and skin bleachers, which he depicts with third person pronoun, It and second person pronoun, Youin the song's chorus (You be man or woman)respectively. Subsequently, he equates/t to Yellow Fever which he also employs as a metaphor forskin bleaching, skin bleachers (You be man or woman) and sickness. The artiste's godlike, omniscient attitude to skin bleaching and its 'perpetrators' is evident in his use of pronoun types (It and You) which 
shows him as an agent of discrimination. Afterall, this also reveals that patriarchal man is infallible, or not susceptible to the sickness. Or is this an artist's prerogative to see/sing about their subjects as objects? Ordinarily, Yellow fever is said to be a serious infectious disease that people can catch in tropical countries. Metaphorically, Fela compares skin bleaching with physiological illnesses like Yellow Fever, Malaria, Jaundice, Hay, Influenza and psychological sicknesses like consequences of economic malady and false sense of freedom. Antithetically, 'original' Yellow Fever is described as somehow natural though more gravely and less fatal in terms of influence, while 'artificial' Yellow Fever is deemed to be usually self-inflicted and far-reaching. Therefore, skin bleaching practice is portrayed as sickness that affects body and mind. Sometimes, skin bleachers are seen in Fela's discourse as prejudiced against women who are euphemistically regarded in the song-texts as Sissiweydey go or African mother in a reverent manner inspite of his initially alluding to both genders (You be man or woman).

Excerpt 2, another chorus, also reveals further metaphoric and euphemistic depictions of bleaching woman's 'yellow' face, black yansh (buttock) and wrinkled skin as consequences of self-wound, though he jeeringly beckons her to heed his reprimands, as is shown in the third chorus:

\section{[Excerpt 2]}

Nigerian Pidgin English

Na lie, you no fine at all

At all, na lie!

\section{English Translation}

It's a lie, you're not beautiful

Not at all, it's a lie!

The tone at the end of the chorus second line shows glaringly Fela's dominantly passionate condemnation of both skin bleaching practice and women skin bleachers. Besides, Teacher which is his metaphor for colonialists or colonial mentality is shown as another social agent that has received considerable flaks in one of the artiste's songs, Teacher, don't teach me Nonsense (1986). However in Excerpt 3 , Fela's use of a similar sentence construction and parallel structure in the stanzas of song-text reveals his use of repetition to harp consistently on the distinctiveness of the subject matter, and the first stanza affirms his purpose: 


\section{[Excerpt 3]}

Nigerian Pidgin English

Different different fever na him dey

Different different fever na him dey

Different different fever na him dey

Different different fever na him dey

\section{English Translation}

There are different fevers

There are different fevers

There are different fevers

There are different fevers

This he later narrows down to one word (fever) religiously in the subsequent stanza to emphasize his message about skin bleaching practice.

\section{[Excerpt 4]}

Yoruba

Dúró b'Ọlọrun bá se dá ę

Má b'àwọ je fẹni bí ẹ...

\section{English Translation}

Stay as God created you

Don't spoil your skin for your parents

On the contrary, in the above excerpt, Ayinla's use of pronoun You is more reverently addressed with skin bleachers, though it is used within the context of imperative statement, Dúró (Stay). Moreover, the dominant agents in Ayinla's skin bleaching discourse consists of the artiste himself, parenthood, lifestyle, bleaching creaming and the Whiteman. All these combine to show the enormity of the discursive essence of the artiste's engagement. First, his use of first person pronoun and active verb structure in (orọ kanje. mí lógún/this matter concerns me) reveals he is more involved as an agent, which also resonates in the excerpt 5 below.

\section{[Excerpt 5]}

Yoruba

Mo fẹ ko yí dà... 
Aànú rę ló se mí...

English Translation

I want you to change...

I feel pity for you...

In (f'ęni bí e/those)who gave birth to you, the eventual consequences of skin bleachingon parents of skin bleachers are also regarded prominently in his discourse and the matter at hand, as he mildly describes skin bleachers as (omoge ìwòyí/modern or wayward ladies; amnbelorun/barren or delayed women) to mean that they have failed in womanhood and motherhood because of their (afę ayél lifestyle) skin bleaching practice. Their failure is even implied in (apon tí ò yo../a meal that doesn't taste good...) and in (òyìnbó ò je. f'aró pa jú.../whiteman won't dye his face...) to condemn the act of skin bleaching and the bleachers.Here, the whiteman/ òyinbó is passively critiqued in the discourse for it is inferred that he will not indulge in skin bleaching though he sold the idea to African women indulging in it (Perry, 2006).

Ayinla further spikes the euphemistic descriptions by directly comparing the skin bleachers to (ọbùn/a dirty person; olopo/a toad; ębora/a daemon; sérékodél a woman prostitute) to show the health and psychological hazards (Charles, 2010; Hunter, 2011; Durosaro, Ajiboye \& Oniye, 2012) of the practice on skin bleachers. In short, while Fela's skin bleaching discourse appears similar with Ayinla's style in the way they focus on social actors, women, whiteman's influence, it is obvious that Ayinla feels more concerned about skin bleaching prevalent among women in his societyand that this practice is more consequential than the manner Fela perceives its effect on the society as a whole. However, their lexical choices of metaphorical and euphemistic expressions about women indulging in skin bleaching practice greatly reflectpatrairchal censoring thoughts on women sexuality. As a matter of fact, the findings reveal that the artistes see women in different ways from how Fei (2014) views them as provider, forgiver and healer. They portrayed them as ignorant skin bleachers and prostitutes who were deceived by colonial mentality, equating good things to white skin (Charles, 2010).

\section{The Artistes' Cognition}

The patriarchal cognitive model which Fela and Ayinla express essentially in the song-texts is echoed by an Egbá historian, Kolawole Ajisafe when he proclaimed that "From childhood to old age, every Egbaman is considered superior to woman" (Adesina, 2015, p. 2). This is an apt depiction of coded patriarchy. The fact that both artistes are 
Egbámen shows how their cognitions have been influenced by this ideology about women in their society. Their understanding of women is mirrored in their use of language, in the lexical choices and thoughtflow patternsin these skin bleaching song texts viz-a-viz women sexuality portrayal. For instance, Ayinla's premise begins from his superiority inclination of 'being concerned' about unbridled spate of skin bleaching among 'modern' women. Of course, he is known to have extensively engaged indiscourse in which women issues feature generally in nearly all his music album releases, notably-Volumes 13, 14, 17 and 20. Therefore, being the self-anointed women 'watchdog', he appears justified to have proclaimed the responsibility to speak out against the craze in town among women-skin bleaching. Subsequently, his first argument to support his propositionreflects this thus

\section{[Excerpt 6]}

Yoruba

Òyìnbíò jẹf'arópajú

Kón'óhun fę dúdú

Kò nísẹ lę...

\section{English Translation}

The white people won't dye their faces

To think to become black

It will never happen...

Indeed, a few of the reviewed studies on skin bleaching practice have so far described Africans (Charles, 2010; Hunter, 2011; Durosaro, Ajiboye \& Oniye, 2012) wanting to whiten their skin pigmentation for various political, psychological and economic reasons or gains. Aró unlike the bleaching cream or soap is a Yoruba black coloured agent solely meant to dye cloth to make àdire clothes, and no whiteman is assumed to so lower himself as to want to darken his skin with a mere local product.Therefore, Ayinla explains that the women's practice of this fad obviously connotes stupidity and lack of self-esteem. Conversely, his second reasoning for berating women bleaching their skin can only be understood to be half-heartered and insincere enough as he states that

\section{[Excerpt 7]}

Yoruba

Mo gbọ tęni tóti bímí

Tónbó jú

eyin ambęíọrun kí le rò? 


\section{English Translation \\ I don't mind mothers}

Who bleach their faces

Expectant ones, how do you think?

This reasoning begs his initial condemnation of the skin bleaching practice among women generally, and shows duplicity in his argument. Could it be that Àyìnlá specificially targeteda certain set of women? Or what does he condemn, women or skin bleaching practice? The implication of his sexist submission at this juncture is that skin bleaching is no longer censored so long only mothers are allowed do it. This shows that as much as he tried to canvassall women to shun this practice he is inavariably lending credence to the assumed socioeconomic gains inherent in it. Also, it shows how the ideal women should be portrayed in his society as this explains the nature of gender relations that exists between men and women in Yoruba society (Olajubu, 2003). Men associate desired attributes to women. For the so called chastised women, Ayinla's admonishing nugget is imbued in the chorus that such women only need to appreciate their natural pigmentation and considerthe effects of their acts on their parents. Moreover, his inclusion of the parent factor in the repercussion of their daughters' misdeed reveals his concern as reflective of communinal way of addressing misbehaviour in an African society. Although he indirectly depicts the health dangers of this practice (Hunter 2011), he paints the women as (oobùn/a dirty person; opọlo/ a toad; ębora/a daemon; sérékodél a woman prostitute) in a ribald language which confirms Adedayo's (2015) submission on the artiste's use of explicitly descriptive expressions for scourging disobedient women. His invectively sarcastic rhetoric styles even reveal glaring dichotomy between his ideas about womanhood and motherhood in connection to skin bleaching and women sexuality. The difference is encapsulated in his parting entreaties to these womenof the analysed song thus

\section{[Excerpt 8]}

Yoruba

Àanú rę ló se mí

Ló je kínbáo dámoràn

Ó ye kó bí méjì kóotó bóra

\section{English Translation}

I only sympathise with you

That's why I advise you

You need to birth two before you bleach skin 
Apparently, this is Ayinla's true woman identity, someone who does not need the pity of the artiste as long as she is a mother first.Indeed, Fela's cognition of skin bleaching practice and women sexualisation is not dissimilar to Ayinla's in the manner he reasons his patriarchal stance against women to condemn 'African personality distorted by a psychology of dependence through skin bleaching' (Olorunyomi, 2005, p. 49), which is in opposition to his activism bend that preaches liberalism. Why were women in the artiste's society not permitted to be liberal in their choices? Like Ayinla, Fela's derisive discourse on women issues can be found in his other songs such as 'Lady', Na Poi', 'Open and Close', and 'Woman na Mattress' as acknowledged by Olorunyomi.

In the first four stanzas of 'Yellow Fever' song text, Felaoffers a didactic explanation to his audience about why skin bleaching, euphemistically tagged 'yellow fever' is more serious a sickness than any other one known to human. Therefore, he argues that the mental and physical effects of this sickness are self-inflicted.

\section{[Excerpt 9]}

Nigerian Pidgin English

Artificial catch you

You be man or woman

$\mathrm{Na}$ you go catch am yourself

$\mathrm{Na}$ your money go do am for you

You go yellow pass yellow

You go catch moustache for face

You go get your double colour

Your yansh go black like coal

\section{English Translation}

If you contracted artificial one

Whether you are a woman or man

You'll inflict it upon yourself

You'll use your own money for it

Your skin will become too toned

You'll get patches in your face

You'll get multiple colours

You'll get multiple colours

Your buttock will get darkened like charcoal

But his social commentary of skin bleaching becomes one sided in the next stanza after he has already generalised the previous stanza that both gender engaged in the practice in his society. This is beyond 
any skin bleacher reaping the consequences of this act. It appears that he then narrows it down to his main target audience-women (African mother, Sissi). These references to women echo how Fei (2014) shows the way musicians sexualise women in their song texts when they want to objectify female gender. It is difficult to see why the two music artistes do not see skin bleaching act, especially among women as a form of self-assertion or self-identity in a patriarchal society as theirs. Moreover, the last few stanzas of Fela's song text are employed to perpetuate the jabs against women's foolishness and self-infliction in relation to skin bleaching practice, and denunciation of colonial mentality, and to reinforce the criticism of the act of defacing black skin.

\section{[Excerpt 10]}

Nigerian Pidgin English

Who steal your bleaching?

Your precious bleaching?

You buy am for shopping

For forty naira

You self all yellow

How you go find out?

Your face go yellow

Your yansh go black

Your skin go scatter

You go die 0

\section{English Translation}

Who steal your bleaching?

Your precious bleaching?

You bought it from shopping

For forty Naira

You have become yellowed yourself

How will you know this?

Your face will be light-skinned

Your buttock will become dark

Your dark patches will show

Your skin will be damaged

You will die

The rhetorical questions in the above text sum up Felá's cognitive thrust; how he engages the discourse of skin bleaching in relation to women sexualisation. The bottom-line is that the artistes' reasoning of 
women's practice of skin bleaching and their objection of the practice are their patriarchal influence over women. They believe that only men should indulge in skin bleaching, and women can only practise it after they have achieved motherhood. Olajubu (2006) encapsulates this as ideology of difference, which eventually reinforces gender constructs with which women sexualisation is given price in Yoruba society.

\section{The Artistes' Societal Ideology}

Ideology, according to van Dijk (2017,p. 12) is"a special form of social cognition shared by social groups". The social cognition displayed in the song-texts of Felá and Àyìnlá is the by-product of the artistes' origin, western education influence, civilisation and colonisation experience. These factors clearlyhave influence on their song-text discourses about skin bleaching practice among female gender in their society. Also, the factors conspire to continue to expose how patriarchal societies cannot do without discriminating against women in all ramifications. Like most human societies, Egba society with its philosophy (Adesina,2015) too is a prime example of patriarchy, though there is a history of how resourceful women like FunmilayoKuti, the mother of FelaKuti, have continued to challenge this status quo.For example, Ayinla emphasises the patriarchal ideology in an average family about its perception of skin bleaching practice among Egbawomen in this chorus

\section{[Excerpt 11]}

Yoruba

Chorus: Durob'Olorunba se da e

Ma b'awo je feni bi e

Kan ma si o mo

T'oriafe aye

\section{English Translation}

Chorus: Stay as God created you

Don't spoil your skin for parents

So that they don't mistake you

Because of world lifestyle

With human society's obsession with and hysterisation of woman's body (Foucault, 1976), the employment of skin bleaching as a focal point of censoring this practice by the artist further reveals how the practice has come to be viewed in the artiste's society. But, the problem 
with this societal ideology can first be noticed from the insincerity of the artiste himself because of his ambivalent view regarding skin bleaching practice among different categories of women. There appears to be this two-faced posture about skin bleaching. Repeating his earlier argument, women who have achieved motherhood are licensed to practise skin bleaching. This attitude reinforces what Fei (2014) said about musicians giving attributes they desire to describe women in their songs. Therefore, skin bleaching is not a question of committing immoral act by the women being hysterised, neither is it a matter of the artist's society calling for the perpetrators to regard their families' names (Don't spoil your skin for parents). The supposed offender's skin represents her family image that should not be tainted. Obviously, the artiste merely invokes his societal and patriarchal authority to describe what men desire from their women, and how they want them to behave. Of course, the artist knows this: when a child misbehaves in his society, the child's parents must know so as to cower such a child. Beyond acting as a moral agent, he uses parents as agents to call to order recalcitrant women he sang about.

Furthermore, the use of abusive/invective expressions to repudiate wrongdoings among people in Yorubaland is common and a widely accepted form of communication in different contexts of communication such as polygamous setting (Lamidi, 2002), protest songs (Olukotun, 2005) and so on. It is no wonder Ayinla's songs are replete with such expressions. While commenting about women lightening their skin, he further affirms his society's ideology about skin bleaching thus:

\section{[Excerpt 12]}

Yoruba

Lead: Mo fekoyi da

Mo se f'orin ran e leti

Kii se eebu

Mo fekomo

So mopebibiniya bi e lomo?

Iwo naa mu raki o bi ti e

Ojo ale la ntoro

Wobiwobi o dara

Se e gbo, kowu lo

\section{English Translation}

Lead: I want you to change So I'm singing to remind you

It's not verbal abuse 
I want to assure you

You know you were born as well

Prepare to give birth to your own

We all pray for latter day

Suffering is not good

It's not useful

The artiste assures women that its verbal abuse of them is meant for correctional purpose, which somewhat agrees partly with what has been indicated as one of the uses of verbal language initially (Lamidi, 2002). However, in spite of his assurance to the contrary regarding women, he shows still that it is meant to control the behaviour of women who lighten their skin in his society. For instance, appellations such as (Iilîibùn/a dirty person; IÎpîllîl/a toad; ' ${ }^{b}$ bíra/a daemon; sérékodél a woman prostitute) are invective expressions used to depict women who bleach their skin in his society. Also, a woman's essence or topmost responsibility according to Ayinla should be fulfilled in reproduction so as to continue the lineage or legacy of the patriarchs (Prepare to give birth to your own). The goal of her sexuality is to reproduce just as she was produced. On the other hand, Felá, though was the much better educated thanAyinla between the two did not fare better in terms of correcting his societal ideology about women sexuality description in their songs.

\section{[Excerpt 13]}

Pidgin English

You dey bleach, o you dey bleach

African mother

You dey bleach, o you dey bleach

Sissiweydey go

Yellow fever

Stupid thing

Yeyething

Fucking thing

Ugly thing

\section{English Translation}

You are bleaching

African mother

You are bleaching

Lady, who is sauntering away

Yellow fever/skin-bleached lady

Stupid human 
Despised thing

Harassed thing/woman

Ugly thing/woman

From the above, skin bleaching attracts denigratingly colourful depictions of women. A woman obviously is venerated when she presents herself as an African mother, but as soon as she ventures into skin bleaching she carries labels such as the ones the artiste employs in the excerpt above. Idolised African mother suddenly turns to wayward lady, to 'stupid', 'yeye', 'fucking', 'ugly', and ultimately, a 'thing'. When she is no longer the community pride (Durosaro et al., 2012), the artiste is certainly aping the societal ideology which patriarchy has deemed so.

Besides, the history of skin bleaching is intimately connected to the oil-boom period in the seventies till early eighties in Nigeria. Though this era had a great impact on all Nigerians' moral values as evident in the then proceeds of oil glut which nobody seemed to know how to handle (Agbaeze, Udeh and Onwuka, 2014; Ejimabo, 2013; Ogbeidi, 2012), social crusaders like some Nigerian artistes, most of whom were males, took pleasures in cataloguing and glowingly sexualising women in their songs as they were being corrupted and were corrupting in turn every other morally upright thing remaining in the Nigerian society as a whole. Afterall, it is a given that women are usually disparaged for any existence of any moral degradation, be it religious, economic, social in any society. To cap it all, Felá offers this sample in the excerpt below.

\section{[Excerpt 14]}

Pidgin English

Who steal your bleaching?

Your precious bleaching?

You buy am for shopping

For forty naira

You self all yellow

\section{English Translation}

Who stole your colour?

Your precious colour?

You bought it from shopping

For forty naira

You have changed yourself

The musician paints skin bleaching as women's pastime, that that is what they were after when they went for shopping, that they 
were much more concerned about the forty naira bleaching cream than its ludicrous effects it had on them. Was this how the women he described used to think then, or how their society thought for them through this artiste?

\section{Conclusion}

Based on the critical analysis of Fela-Kuti's and Ayinla Omowura's songs, as they relate to their descriptions of womenin relation to their skin bleaching practice, obviously, they should have been agents of societal change indeed for discouraging the prevalence of skin bleaching practice not just among women folk alone. Of course, skin bleaching practice should be discouraged among male and female who practise this because of its health hazards (Ajose, 2005); yet, male musicians should dig deep when commenting about an issue as skin bleaching practice should not only cast aspersions to easy preys like women, they should take holistic approach to expose all the culprits in this debacle, right from the governments, leaders, elite who encourage people's and country's recolonisation through their actions and inactions. That is what is referred to as justice and equity with which any social crusader ought to be concerned. After all, studies have unveiled the reasons behind people engaging in skin bleaching. Mere objectification of women as done by the artistes will not wish away skin bleaching practice with its attendant negative effects or ensure the artistes' target audience imbibe the homilies they preach about moral uprightness. In spite of the fact that the artistes' society readily gives them weapons to objectify women, they should consciously ensure they balance views without resorting to disparaging words and expressions. Even though these artistes are late, new and existing male artistes can afford to learn from their mistakes, especially when they intend to engage in discourse of minorities, for example, women in their respective societies. The fact that evidence displays glaring bias towards women's portrayal in the two artistes' song-texts vis-àvis societal skin bleaching malaise shows that patriarchal society will always focus on women as scapegoats of its moral decadence. 


\section{References}

Aboh, R. and Uduk, H. (2017). Meaning in discourse: An introduction to discourse analysis. Ibadan: Kraft Books Limited.

Adedayo, F. (2015). Ayinla Omowura: 35 years after. Sunday Tribune, pp. 59-60.

Adesina, K. (2015). Omowura's music as journalism: Thirty five years. Retrieved 2 May 2018, from http://www.mynewswatchtimesng. com/omowuras-music-asjournalism-thirty-five-years-on.

Ajose, F.O.A. (2005). Consequences of skin bleaching in Nigerian men and women. International Journal of Dermatology, 44, 41-43.

Balder, S. (2005). Marginalization of alternative gender and sexual identities: The role of normative discursive practices in Chilean society. Colorado Research in Linguistics, 18, 1-11.

Charles, C.A.D. (2010). Skin bleaching in Jamaica: Self-esteem, racial self-esteem, and black identity transactions. Caribbean Journal of Psychology, 3(1), 25-39.

Dahl, D.W., Sengupta, J. \& Vohs, K.D. (2009). Sex in advertising: Gender differences and the role of relationship commitment. Journal of Consumer Research, 36, 57-63. DOI: 10.1086/ 597158.

Durosaro, A. I. Ajiboye, S. K. \& Oniye, A. O. (2012). Perception of skin bleaching among female secondary school students in Ibadan Metropolis, Nigeria. Journal of Education and Practice, 3 (7), 40-46.

Agbaeze, E.K., Udeh, S.N. \& Onwuka, I.O. (2014). Resolving Nigeria's dependency on oil: The derivation model. Journal of African Studies and Development, 7(1), 1-14.

Ejimabo, N.O. (2013). Understanding the impact of leadership in Nigeria: Its reality, challenges, and perspectives. Sage Open, 7, 114. DOI: $10.1177 / 2158244013490704$.

Fei, J. (2014). The manifestation of sexual repression, gender in popular music: A case study on Katy Perry. Canadian Social Science, 10(2), 44-49.

Foucault, M. (1978). Tran. The history of sexuality: An introduction, Vol. 1. New York: Pantheon Books.

Hunter, M. L. (2011). Buying racial capital: Skin-bleaching and cosmetic surgery in a globalized world. Journal of Pan African Studies, 4 (4), 142-164.

Igboin, B. (2011). Colonialism and African cultural values. African Journal of History and Culture, 3(6), 96-103. 
Iwilade, A. (2010). Gender and identity in the Nigerian media. Ibadan Journal of Humanistic Studies, 19 \& 20, 68-89.

Kuti, F. A. (1976). Yellow Fever/Na Poi. France: EMI-Music-PublishingFrance/ https://www.discogs.com/label/237995

Makama, G. A. (2013). Patriarchy and gender inequality in Nigeria: The way forward. European Scientific Journal, 9(17), 115145.

Makura, A. H. (2016). The glorification of patriarchy in Paul Matavire's music lyrics. Muziki, 13(2), 3-19. DOI: 10.1080/ 18125980.2016.1249160.

Ogbeidi, M.M. (2012). Political leadership and corruption in Nigeria since 1960: A socio-economic analysis. Journal of Nigeria Studies, 1(2), 1-25.

Olajubu, O. (2003). Women in the Yoruba religious sphere. Albany: State University of New York Press.

Oloruntoba-Oju, T. (2011).Sexuality, language and communication in Africa. Sexuality in Africa Magazine \& Monograph, 7(2).

Olorunyomi, S. (2005). Afrobeat! Fela and the imagined continent. Ibadan: The French Institute for Research in Africa (IFRA).

Olukotun, A. (2005) Repressive state and resurgent media under Nigeria's military dictatorship, 1988-98. Ibadan: College Press \& Publishers Ltd.

Omowura, A. (1978). AtiD'ariyo. (LP; EMI NEMI 0417)(CD) Lagos: Ivory Music.

Perry, I. (2006). Buying white beauty. Cardozo Journal of Law \& Gender, 12, 579-607.

Robinson, P.A. (2011). Skin bleaching in Jamaica: A colonial legacy. Dissertation, Texas A \& M University.

van Dijk, T.A. (2017). Discourse, ideology and context. Folia Linguistica XXXV/1-2, Berlin: Societas Linguistica Europaea, 11-40.

van Leeuwen, T. (2012). Music and ideology: Notes toward a sociosemiotics of mass media music. Popular Music and Society, 22(4), 25-54. DOI: 10.1080/03007769808591717. 